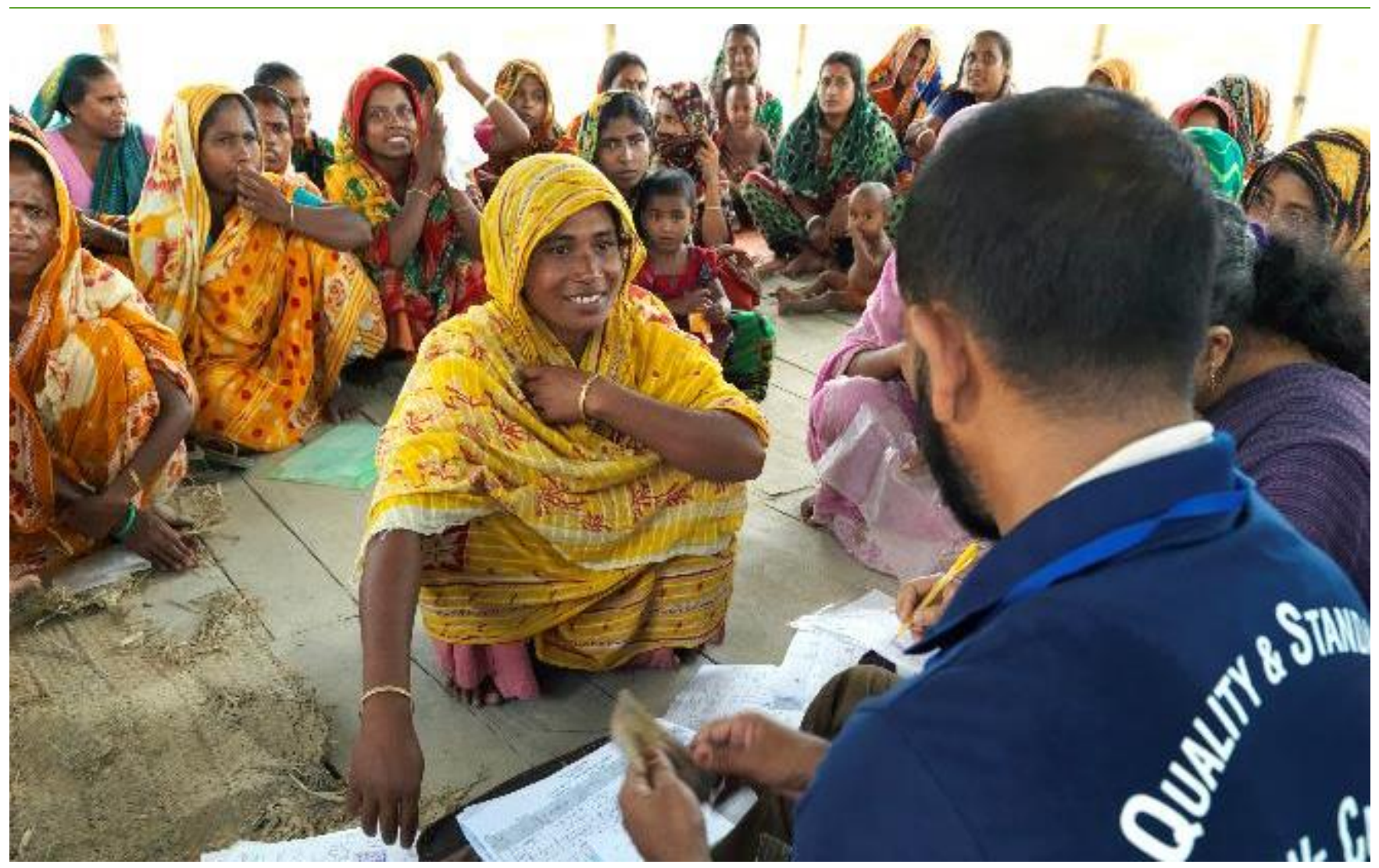

The FRESH project, delivered through a consortium of six INGOs and four local NGOs in Bangladesh, encouraged residents to build their own homestead plinth in order to raise and protect their homes from floods, for which they are paid. Anjuara received 3,000 Tk $(\$ 38)$ for her work. Photo credit: Peter Caton/Oxfam

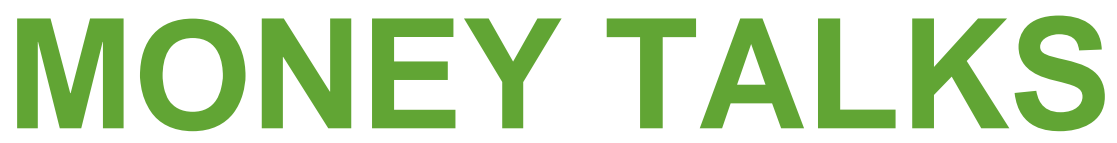

\title{
A synthesis report assessing humanitarian funding flows to local actors in Bangladesh and Uganda
}

International humanitarian agencies and donors have made a series of global commitments to local actors as part of the localization agenda, including to increase their access to greater direct funding by 2020. This briefing paper reviews 2015 national financial data for Bangladesh and Uganda to better understand how to target international investments in localization. It presents key findings from Oxfam-commissioned research on which factors affect local actors' ability to access international humanitarian funding. It concludes that in order for global commitments to translate into practice, investments should look at changing the terms of the funding relationship, as well as be based on a context-specific, national analysis of the financial environment.

\section{development initiatives

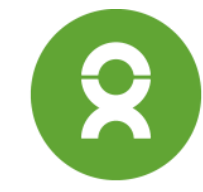




\section{ACRONYMS}

GoB: Government of Bangladesh

GoU: Government of Uganda

INGO: International non-government organization

LNHA: Local and national humanitarian actor

NNGO: National non-government organization

RCNS: Red Cross or Red Crescent National Society (Bangladesh or Uganda)

RCRC: IFRC, ICRC, and national societies providing or channeling funding

\section{GLOSSARY}

Localization: Oxfam, based on feedback from partners and ongoing consensus in the sector, defines localization as a transformational process to recognize, respect, and invest in local and national humanitarian and leadership capacities, to better meet the needs of crisis-affected communities.

Donor: For the purposes of this paper, "donor" refers to the original source of the funds.

Private donor: Refers to individuals, companies, or foundations to distinguish from institutional donors providing government funding. This category does not include UN agencies. Private funding, as such, comes from private donors.

Local and national humanitarian actors (LNHAs): Refers to national and subnational governments, the national Red Cross or Red Crescent societies, local and national NGOs and civil society, including media, community-based organizations (CBOs), faith-based organizations, as well as local and national private sector actors. This definition is taken from the Inter-Agency Standing Committee's Humanitarian Financing Task Team (IASC HFTT) definitions paper (March 2017). ${ }^{1}$

Local actors: For reporting purposes, LNHAs are referred to synonymously with local actors.

NNGOs: Due to constraints in the dataset, local and national NGOs are both included under the heading of national NGOs (NNGOs).

Direct funding: Funding given by the original donor directly to the ultimate recipient agency (implementing partner).

First-level funding/recipient: Funds reaching the first recipient agency from a donor, before being passed on to another recipient agency.

Indirect funding: Funding that is channeled through one or more intermediary organizations between the original donor and the ultimate recipient agency (implementing partner). Note, current discussion on funding which is "as directly as possible" includes one intermediary, whereas in this report, one intermediary falls within indirect funding. 
Local and national actors are often the primary responders in humanitarian crises. However, within the international humanitarian architecture they tend to act as "subcontractors" to international agencies-UN agencies, international non-governmental organizations (INGOs) etc.- who are often the first-level (direct) or even second-level (indirect) recipients of humanitarian funding from international donors. Despite their essential role in crisis response, data shows that local and national humanitarian actors (LNHAs) only receive a small proportion of international humanitarian assistance directly from donors (2 percent in 2016). ${ }^{2}$ This has serious implications for LNHAs' capacity, sustainability, and influence, as well as on the efficiency, effectiveness, and accountability of the humanitarian sector as a whole.

In the consultations leading up to the first World Humanitarian Summit, "localization" of aid was considered an essential next step in systems change, which would bring not only "short-term efficiency gains but also promote local ownership, strengthen local civil society more generally, and increase that society's capacity to manage future shocks." ${ }^{3}$ The summit, held in May 2016, saw many international actors, including donor governments, UN agencies, INGOs, and Red Cross Red Crescent (RCRC) societies, and a handful of local actors, make a series of ambitious commitments to invest in LNHAs in crisis response-referred to as the "localization" of humanitarian financing (See Box 1). At the forefront of these commitments is a target to channel at least 25 percent of humanitarian funding "as directly as possible" to LNHAs by $2020 .{ }^{4}$ Certainly, greater access to financing alone may not be the only answer to increasing the role of LNHAs - it also requires qualitative improvements in the funding, structure, and design of assistance, which are the subject of a wider set of commitments and initiatives by INGOs and governments. ${ }^{5}$

Yet these commitments were based, in part, on global-level, aggregated data and trends. A closer look at funding available to LNHAs at the country level and how it reaches them can provide a more detailed understanding of the broader context and role LNHAs play, e.g., by shedding light on the extent and nature of their involvement in internationally-funded humanitarian responses and revealing what progress has yet to be made to support their strengthened role. This report contributes to closing the knowledge gap between global and country-level financing solutions with practical suggestions on how the sector can fulfil its commitment to LNHAs. 


\section{Box 1: "Localization Commitment" in the Grand Bargain ${ }^{6}$}

\section{Commitment 2: More support and funding tools for local and national responders}

National and local responders comprising governments, communities, Red Cross and Red Crescent National Societies, and local civil society are often the first to respond to crises, remaining in the communities they serve before, after, and during emergencies. We are committed to making principled humanitarian action as local as possible and as international as necessary, recognizing that international humanitarian actors play a vital role, particularly in situations of armed conflict. We engage with local and national responders in a spirit of partnership and aim to reinforce rather than replace local and national capacities.

Aid organizations and donors commit to:

1. Increase and support multi-year investment in the institutional capacities of local and national responders, including preparedness, response, and coordination capacities, especially in fragile contexts and where communities are vulnerable to armed conflicts, disasters, recurrent outbreaks, and the effects of climate change. We should achieve this through collaboration with development partners and incorporate capacity strengthening in partnership agreements.

2. Understand better and work to remove or reduce barriers that prevent organizations and donors from partnering with local and national responders, in order to lessen their administrative burden.

3. Support and complement national coordination mechanisms where they exist and include local and national responders in international coordination mechanisms as appropriate and in keeping with humanitarian principles.

4. Achieve by $2020 \mathrm{a}$ global, aggregated target of at least 25 percent of humanitarian funding to local and national responders as directly as possible to improve outcomes for affected people and reduce transaction costs.

5. Develop, with the Inter-Agency Standing Committee (IASC), and apply a "localization" marker to measure direct and indirect funding to local and national responders.

6. Make greater use of funding tools which increase and improve assistance delivered by local and national responders, such as UN-led country-based pooled funds (CBPF), the IFRC Disaster Relief Emergency Fund (DREF), and NGO-led and other pooled funds.

\section{METHODOLOGY}

This report is based on quantitative and qualitative research carried out by Oxfam in Bangladesh and Uganda. The studies aimed to understand the nature of LNHAs' current share in the financing and delivery of international humanitarian assistance at the national level; their perception of their role and the barriers and enablers to greater involvement; and the volume of international funding they receive and how it reaches them. ${ }^{7}$

This report's quantitative analysis is based on data gathered for both countries, looking at fiscal year 2015. It was not feasible, for this research project, to collect data for more than one year, and thus this report does not analyze funding trends to LNHAs in Bangladesh and Uganda over time. 
However, the report does demonstrate funding flows over the course of one year, 2015, in which there were no unusual peaks or troughs in comparison to other years-which may serve as a useful baseline measure. As reporting practices improve, Oxfam hopes to reproduce similar analysis in future years and, in time, assess other trends.

Primary data was provided by donors, UN agencies, INGOs, RCRC societies, and LNHAs, and complemented by secondary data from UN OCHA's Financial Tracking Service (FTS) and the OECD DAC's Creditor Reporting System (CRS), to which international humanitarian donors and agencies report standardized information on their funding and activities.

There are some noteworthy limitations to the data. Firstly, the data presented in this report only covers what was possible to collect for the purposes of the study. While it represents a significant proportion of international humanitarian funding to Bangladesh and Uganda provided in 2015, it was not possible to capture data for all funding - a fact that is closely tied to the accuracy of available system-wide data and obligatory versus optional reporting of data by various agencies. The figures for RCRC consist of funds which flowed through the international headquarters of the International Committee of the Red Cross, and funds reported to the FTS, CRS or directly to Oxfam by the donor or recipient agency as part of this study. As such, RCRC figures do not include all funds given directly to or between national societies. It is also important to note that the data collection process in Uganda was interrupted and required an adapted approach. ${ }^{8}$ Consequently, all data on UN funding in Uganda was provided by UNHCR, which appears to work more with LNHAs than other UN agencies. The resulting analysis may therefore not be representative of broader UN funding.

Hence, throughout the report, we refer to "identified" and "investigated" funding. "Identified" funding refers to humanitarian funding to Bangladesh identified as part of this study. "Investigated" funding refers to the funding for which data was available or provided to show how much reached LNHAs, if at all.

The qualitative element to this study involved interviews with a range of LNHAs in both countries, as well as with international agencies and donors. This report includes a summary of the key qualitative findings and recommendations. ${ }^{9}$

The intention of this study was to include disaggregated analysis of LNHAs that have a specific mandate on the rights and needs of women and girls in emergencies. However, the data from interviews of such LNHAs was too limited to provide conclusive or comparable analysis. ${ }^{10}$ Oxfam intends to conduct more specific research to better reflect the role of local and national women's rights and women- and girl- focused agencies.

Bangladesh and Uganda were selected for this research study as part of a multi-year Oxfam program, Empowering Local and National Humanitarian Actors (ELNHA), funded by the IKEA Foundation. The ELNHA program operates on the principle of putting LNHAs in the driver's seat to define their agenda and strategies while influencing international humanitarian actors 
for their support. It includes, among its priorities, promoting a better understanding of funding modes and amounts allocated from donors to local actors to better define potential areas of influence and advocacy, inevitably making more funding accessible to local actors.

In addition, the comparative approach provides interesting insights into the practicalities of localization, as the countries commonly experience different types of crises-Bangladesh is prone to frequent natural, or climate-related, emergencies, ${ }^{11}$ while Uganda hosts significant numbers of refugees. They also differ in their domestic capacity and available resources, as well as have very different humanitarian architecture, giving contrasting perspectives on localization issues, and demonstrating a need for contextspecific application of global commitments. 


\section{FUNDING TO LOCAL ACTORS IN BANGLADESH AND UGANDA: COMPARING THE DATA}

This research identified $\$ 62$ million in humanitarian funding from international donors to Bangladesh in 2015. The equivalent figure for Uganda was more than double this amount, at $\$ 166$ million, reflecting the scale of needs in the country, limited national resources to respond, and the existence of UN-coordinated appeals for Uganda. Of the total identified funding for Bangladesh, at least $\$ 12$ million (20 percent) is known to have been given directly to LNHAs, though this consisted entirely of funding from international government donors to the Government of Bangladesh (GoB). A very small amount of direct funding to LNHAs in Uganda was identified, also provided from international government donors to the domestic government (Government of Uganda, hereafter GoU).

A further $\$ 12.2$ million of investigated funding was given indirectly to LNHAs in Bangladesh via international agencies such as the UN, INGOs, and RCRC societies. This brought the total amount of international humanitarian funding known to have been directly or indirectly transferred to LNHAs in Bangladesh to at least $\$ 25$ million-39 percent of all funding identified in this study. In Uganda, this figure was just $\$ 19$ million-12 percent of the total. The remaining $\$ 38$ million in Bangladesh and $\$ 147$ million in Uganda was either used by international actors to provide assistance or could not be tracked by this study. ${ }^{12}$

Figure 1: International humanitarian funding to LNHAs in Bangladesh and Uganda, 2015 (US\$ million)

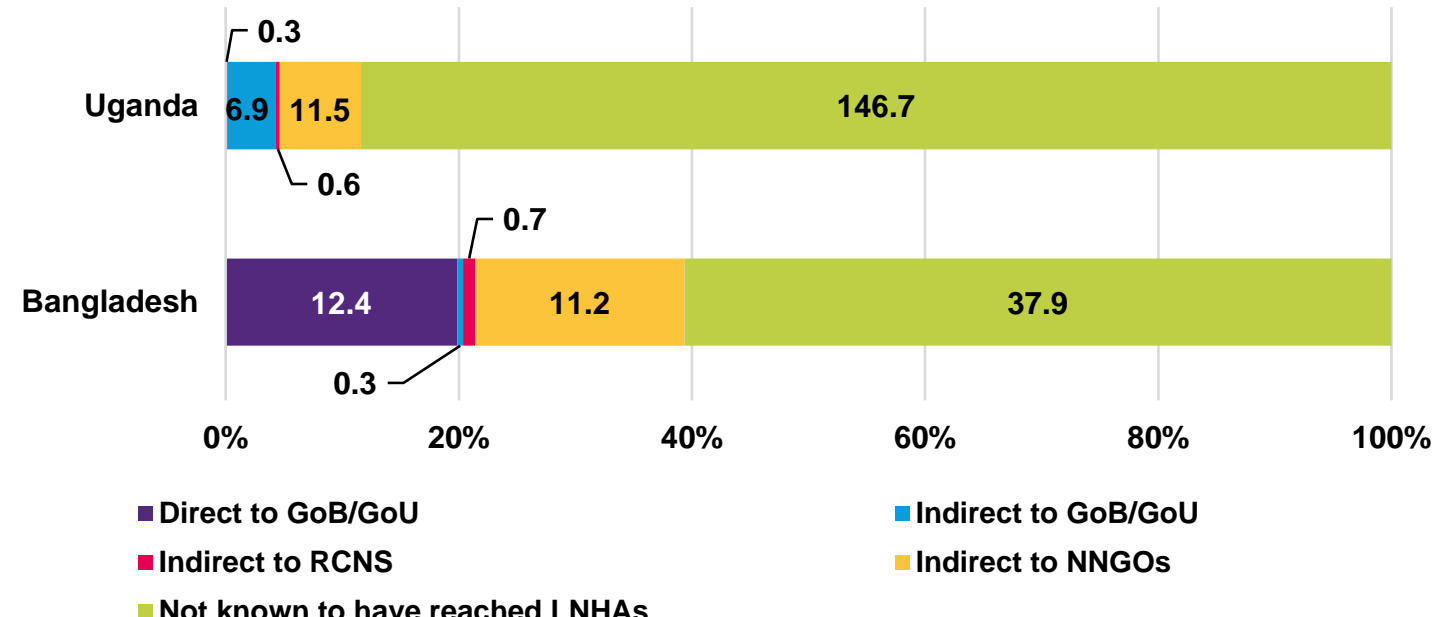

Sources: Development Initiatives based on UN OCHA FTS, OECD DAC CRS, CERF (Central Emergency Response Fund), and ICRC data, and primary data provided by study participants.

As can be seen in figure 1, in both countries, NNGOs appear to receive most indirect funding to LNHAs. When combining direct and indirect funding 


\section{BANGLADESH: KEY FINDINGS}

Bangladesh is one of the most environmentally vulnerable countries in the world. Floods, cyclones, earthquakes, and landslides are all relatively common, affecting millions of people each year. Climate change and population growth will likely further increase the country's exposure to these types of hazards in the future. ${ }^{13}$ The GoB plays a leading role in the planning, delivery, and coordination of disaster prevention, preparedness, and response, and has invested heavily in disaster risk management. Bangladesh also hosts hundreds of thousands of Rohingya refugees from neighboring Myanmar, which was the case even before the large-scale displacement in 2017 more than tripled the refugee population to over $900,000 .^{14,15}$

The main sources of humanitarian financing in Bangladesh are the domestic government through the Ministry of Disaster Management and Relief and international assistance provided by foreign governments and private donors. Between 2012 and 2016, annual domestic government funding for humanitarian-related activities ranged between $\$ 715$ million and $\$ 1.1$ billion. ${ }^{16}$ Contrary to the perception of LNHAs interviewed, humanitarian funding from international donors was significantly lowerbetween $\$ 32$ million and $\$ 41$ million was reported to UN OCHA's FTS in the same period. ${ }^{17}$ One caveat: the focus of this study is on international funding provided to LNHAs, which includes the GoB, and as such, the nature of NNGO funding secured from the government has not been explored.

LNHAs in Bangladesh appear to access and receive a significant proportion of international humanitarian financing provided to the country-39 percent in 2015, according to data collected for this study. However, these are not through funds provided directly to them; instead, funds pass through international agencies before reaching LNHAs under subcontracting-style agreements.

Between 2012-2016, annual GoB funding for humanitarianrelated activities ranged between $\$ 775$ million and $\$ 1.1$ billion, exceeding international humanitarian assistance every year. 


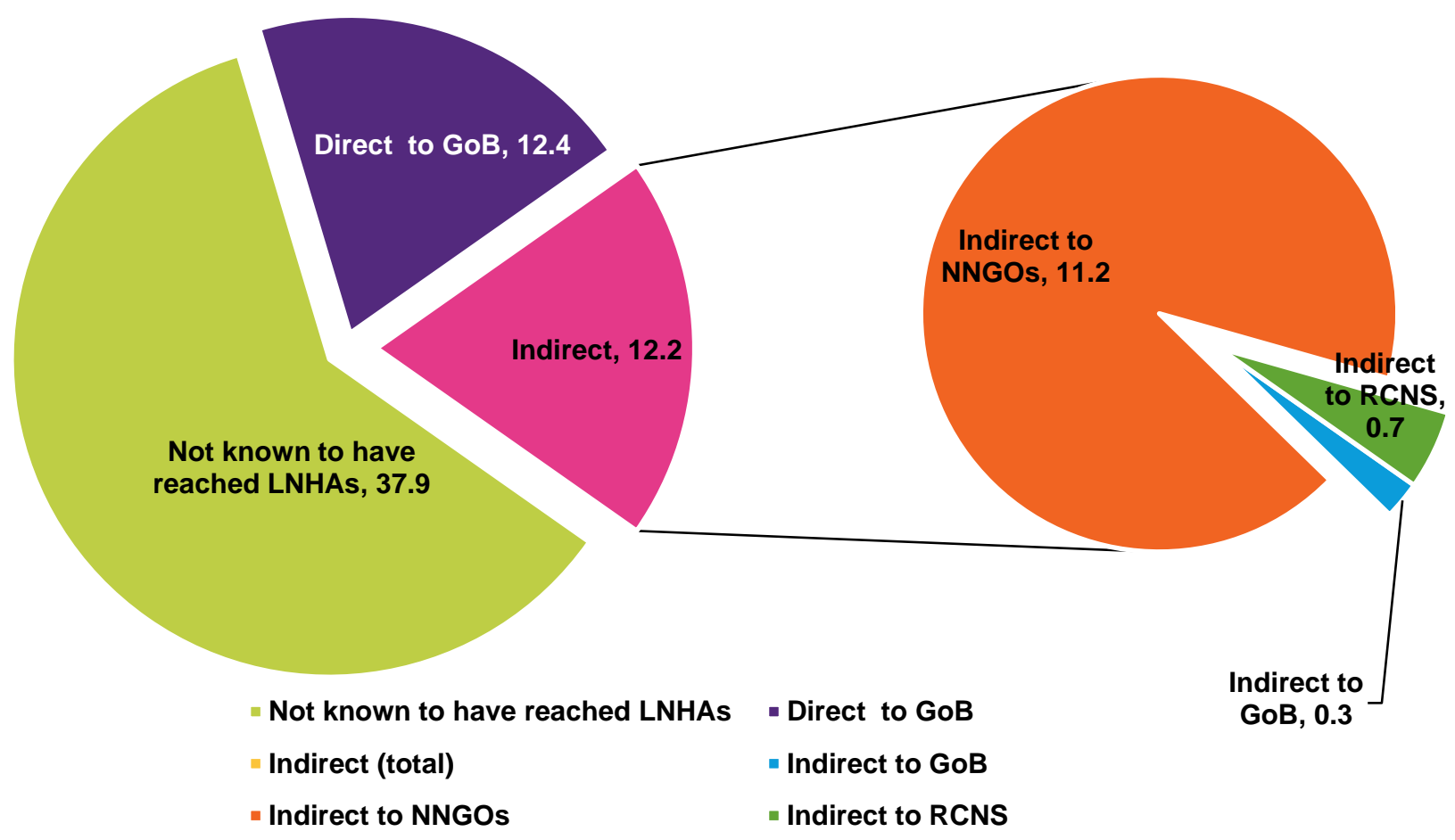

Sources: Development Initiatives based on UN OCHA FTS, OECD DAC CRS, CERF, and ICRC data, and primary data provided by study participants.

This study identified $\$ 62.5$ million of international humanitarian funding provided to Bangladesh in 2015, represented in figure 2. Data collected showed that $\$ 12.4$ million (20 percent) of this figure was provided by the original donor directly to the GoB. ${ }^{18,19}$ No funds were provided directly to other types of LNHAs (whether NNGOs or the Bangladesh Red Crescent Society (RCNS)). ${ }^{20} \mathrm{~A}$ further $\$ 12.2$ million was indirectly transferred to LNHAs, first channeled through other actors, bringing the total they received to $\$ 24.6$ million (39 percent of all identified funding). Most indirect funding (\$11.2 million) went to NNGOs.

Figure 3: International humanitarian funding to Bangladesh channeled through INGOs, UN agencies, and RCRC, 2015 (US\$ million)

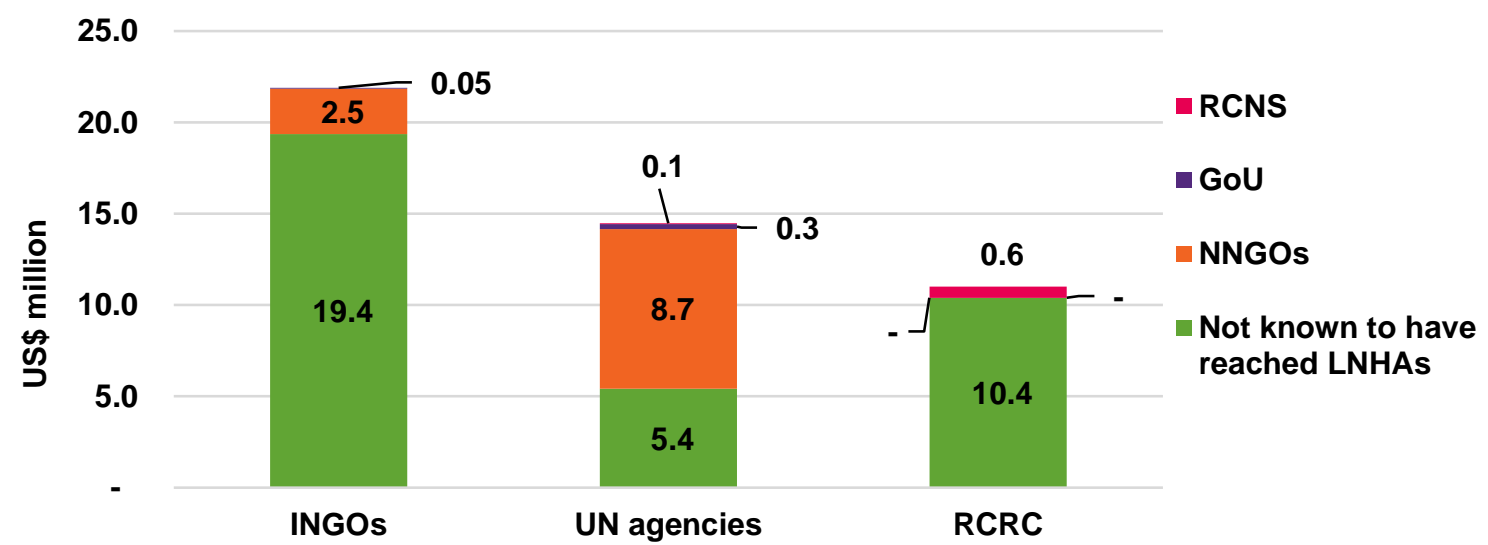

Sources: Development Initiatives based on UN OCHA FTS, OECD DAC CRS, CERF, and ICRC data, and primary data provided by study participants. 
Excluding direct funding to the GoB from the Government of Japan, figures 3 (above) and 4 (below) show that INGOs received the most first-level funding (\$21.9 million, or 35 percent of the total) from donors.

Figure 4: First-level recipients of international humanitarian funding to Bangladesh by donor type, 2015

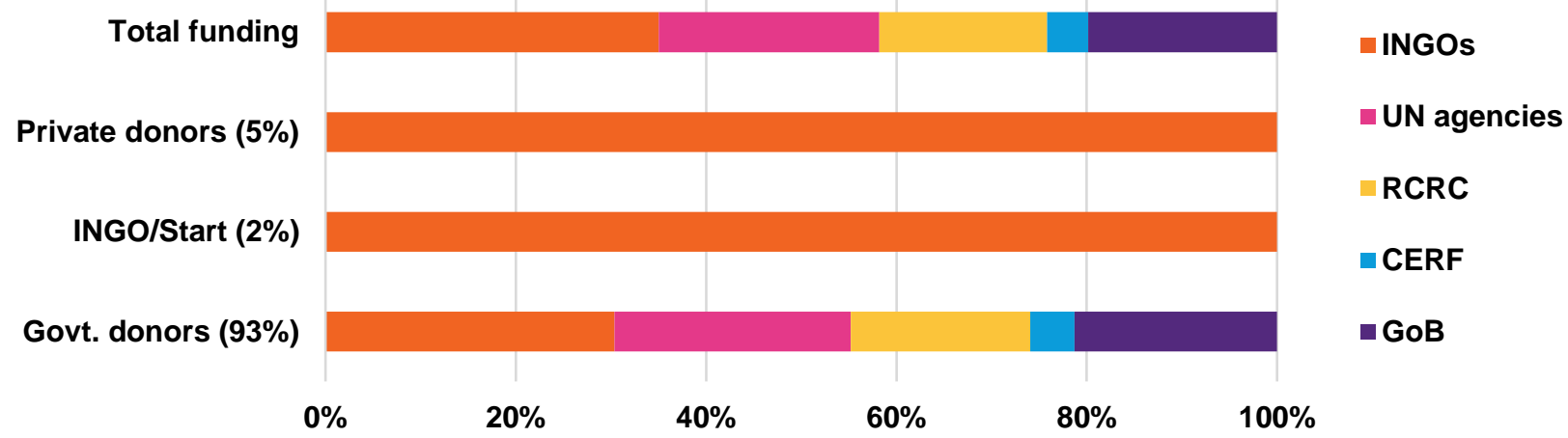

Sources: Development Initiatives based on UN OCHA FTS, OECD DAC CRS, CERF, and ICRC data, and primary data provided by study participants. Note: "INGO/Start" refers to INGO donors and the INGO-led Start Fund.

All investigated private funding and funding from INGO donors and the INGO-led Start Fund went to INGOs, as did the greatest share of investigated government funding. UN agencies received $\$ 14.5$ million (23 percent of the total) and $\mathrm{RCRC}$ received $\$ 11.0$ million (18 percent).

Figure 5: International humanitarian funding to LNHAs in Bangladesh channeled through INGOs, UN agencies, and RCRC, 2015.

\section{UN agencies}

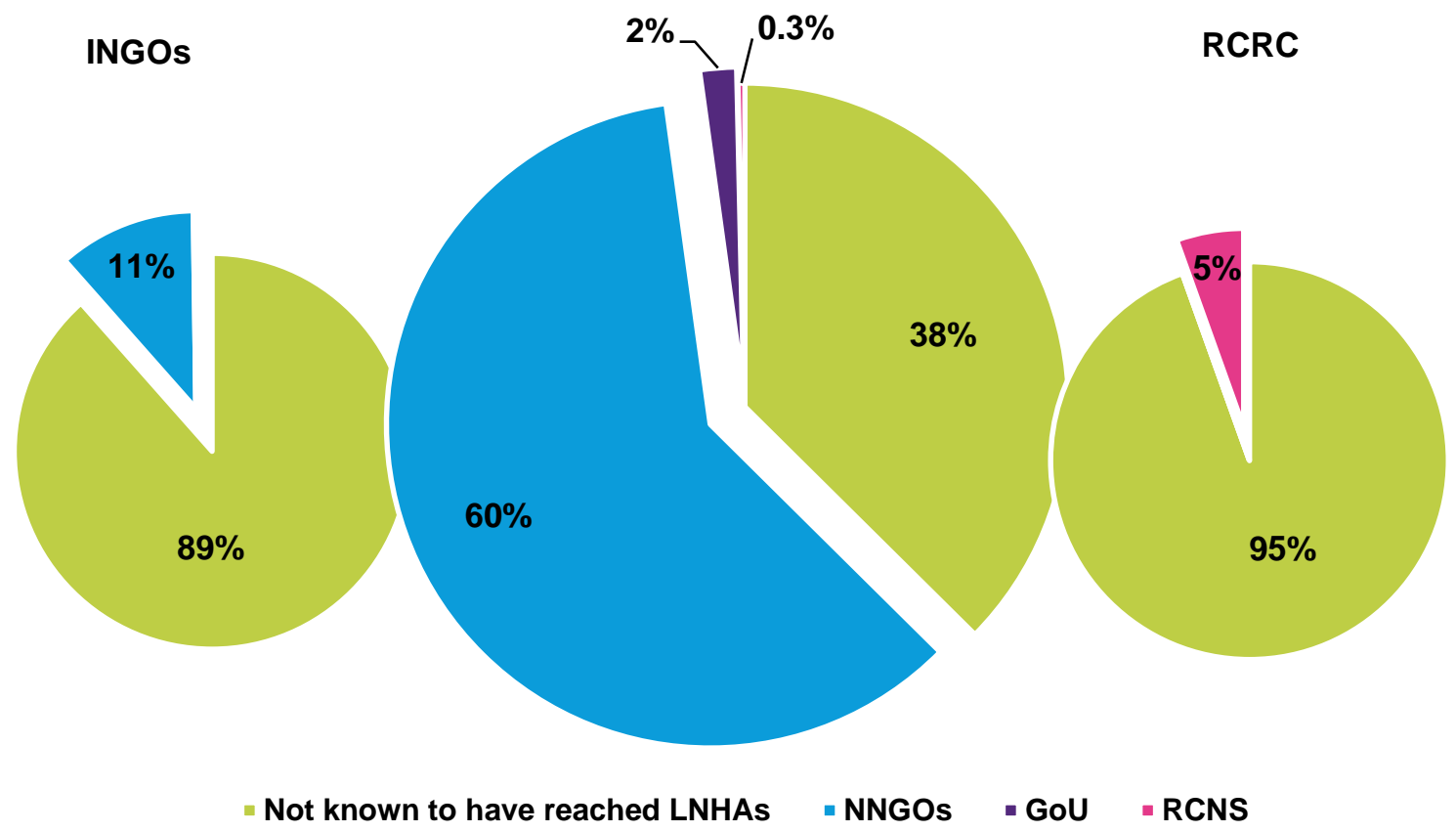

Sources: Development Initiatives based on UN OCHA FTS, OECD DAC CRS, CERF, and ICRC data, and primary data provided by study participants. 
The data shown in figure 5 above suggests UN agencies transferred a greater share of the funds they received to LNHAs than INGOs and RCRC did. At least 63 percent of funding channeled through UN agencies $(\$ 9.1$ million) was transferred to LNHAs; the equivalent figures for INGOs and RCRC were 12 percent ( $\$ 2.5$ million) and 5 percent ( $\$ 0.6$ million), respectively. The majority of funding transferred to LNHAs by both UN agencies and INGOs went to NNGOs, while all RCRC funding transferred to LNHAs was provided to the Bangladesh Red Crescent Society.

Figure 6: International humanitarian funding received by LNHAs in Bangladesh by funding source, 2015

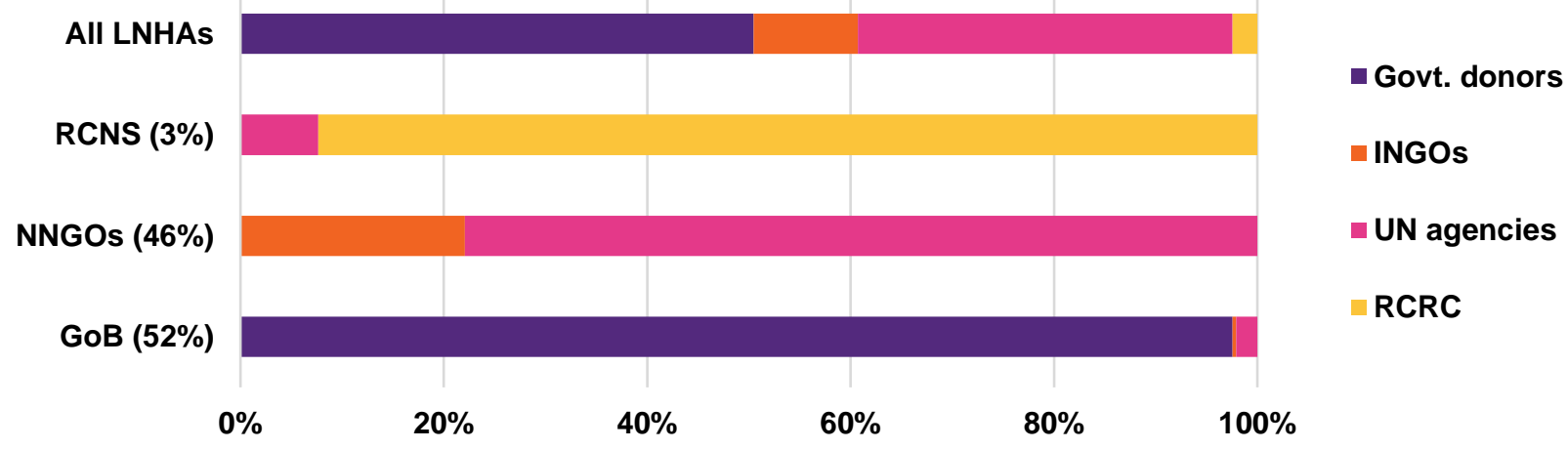

Sources: Development Initiatives based on UN OCHA FTS, OECD DAC CRS, CERF, and ICRC data, and primary data provided by study participants.

Figure 6 shows that international humanitarian funding sources for LNHAs were mixed, depending on the type of organization. Almost all international humanitarian funding investigated for this study provided to the GoB originated from government donors. 78 percent of funds received by NNGOs came from UN agencies, and 22 percent came from INGOs. This division reflects the fact that, although UN agencies received less total funding than INGOs, they appear to have transferred a greater share and volume to LNHAs. Additionally, most funding provided to the Bangladesh Red Crescent Society came from other RCRC societies.

The fact that almost 40 percent of the international humanitarian funding to Bangladesh investigated for this study was ultimately received by LNHAs suggests a strong domestic civil society and government, with significant responsibility for delivering internationally-funded humanitarian assistance. However, the extent to which receiving funding and being responsible for the delivery of assistance translates into local ownership of humanitarian strategies and programming is unclear.

Additionally, despite the above, some LNHAs reported that indirect funding in internationally-funded humanitarian responses limited opportunities to engage in decision-making. ${ }^{21}$ Perceived barriers to accessing direct funding include a lack of capacity in proposal writing and grant management; weak English language skills; domestic competition and dominance of one or two very strong NNGOs preventing others from accessing funding; and lack of trust by international actors to manage funds. ${ }^{22}$ Long-standing dynamics and relationships also make it difficult for LNHAs to challenge the status quo, and international agencies are seen to be in the driving seat when it comes to setting agendas due to their size and existing relationships with 
donors. Finally, a lack of local leadership and representation through formal networks dampens the collective voice and limits collective negotiating power.

Recommendations to address some of the key barriers identified by those interviewed include building the capacity and financial sustainability of LNHAs; encouraging more joint funding proposals between international agencies and LNHAs; and, given the significant and growing volume of domestic funding for disaster management, aligning international actors' humanitarian strategies with the GoB's disaster management plan to strengthen relationships between the GoB and other LNHAs.

Whether and how a shift from indirect to direct funding of domestic actors could lead to greater ownership for LNHAs over high-level processes and decision-making, as well as increasing their organizational stability, is not yet clear. Any changes to international funding mechanisms should be designed to support this aim of increased ownership and decision-making, and its impact on capacity, sustainability, and leadership for local actors should be closely monitored. Perhaps most important is to monitor over time whether these shifts in ownership and decision-making have the intended impact: that communities receive the assistance they need, when they need it.

\author{
Any changes to \\ international funding \\ mechanisms should \\ be designed to \\ support this aim of \\ increased ownership \\ and decision- \\ making, and its \\ impact on capacity, \\ sustainability, and \\ leadership for local \\ actors should be \\ closely monitored.
}




\section{UGANDA: KEY FINDINGS}

Uganda currently hosts over a million refugees, most of whom have fled violence in South Sudan, and the majority (more than 80 percent) live in remote and less developed settlements within host communities. ${ }^{23}$ In addition, recent reports indicate that food security is deteriorating across the country-with an estimated 1.6 million people (or 5 percent of the population) experiencing crisis levels of food insecurity and depending on "food assistance, remittances from relatives, begging, stealing food, wild food gathering, and irreversible sale of productive assets to buy food." 24

Government capacity to meet these needs is limited, particularly at the subnational level and in districts hosting large numbers of refugees, as in West Nile. ${ }^{25}$ Despite considerable economic growth from the mid-2000s, poverty reduction has not kept pace: in 2016, Uganda's gross national income (GNI) per capita, which reflects the average income of citizens, was among the lowest in the world. ${ }^{26}$ As a result, it is likely that more international funding was required in 2015, and continues to be required to help meet humanitarian needs.

LNHAs in Uganda appear to receive a much smaller proportion of overall international humanitarian funding entering the country than those in Bangladesh. This study identified just $\$ 19.3$ million in 2015 , only 11 percent of the total. Apart from a very small amount provided directly to the GoU by international governments (less than 0.2 percent), there was no evidence of any further international humanitarian funding being given directly to LNHAs in Uganda, suggesting that the majority of funding they receive is as subcontractors to international agencies.

\section{Figure 7: Direct and indirect international humanitarian funding to LNHAs in} Uganda, 2015 (US\$ million)

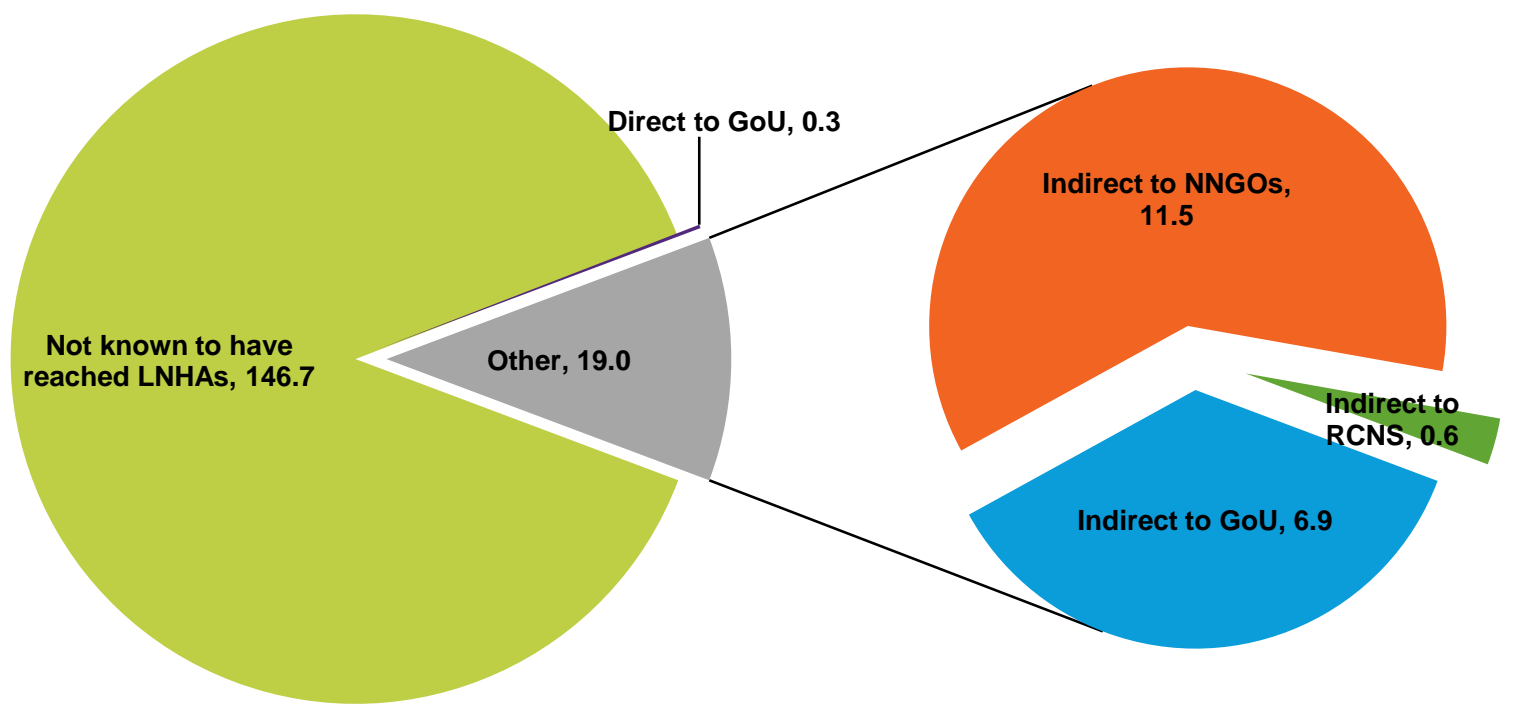

Sources: Development Initiatives based on UN OCHA FTS, OECD DAC CRS, CERF, and ICRC data, and primary data provided by study participants. 
This study identified $\$ 166$ million of international humanitarian funding to Uganda in 2015, nearly all of which was provided to international actors such as INGOs, UN agencies, and RCRC. $\$ 19$ million (11 percent) of this overall amount went on to be transferred to LNHAs indirectly.

Figure 8: International humanitarian funding to LNHAs in Uganda channeled through INGOs, UN agencies, and RCRC, 2015

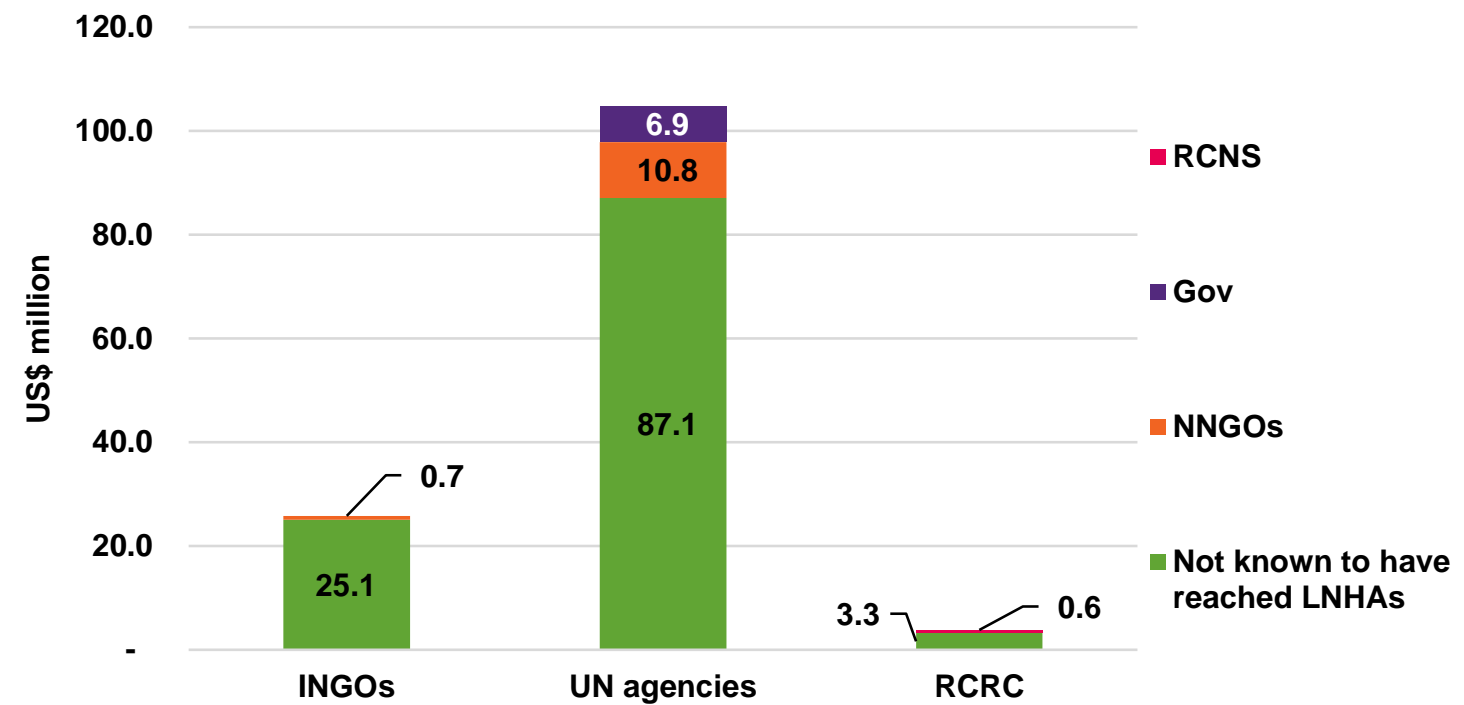

Sources: Development Initiatives based on UN OCHA FTS, OECD DAC CRS, CERF, and ICRC data, and primary data provided by study participants. This graph and first-level recipient analysis below does not include $\$ 28.1$ million in carry-over funding to UN agencies, which was originally donated in previous years.

Figures 8 (above) and 9 (below) show that UN agencies in Uganda received, by far, the most first-level funding from donors - 76 percent of total investigated funding ( $\$ 104.8$ million, of which $\$ 65.1$ million was provided to UNHCR due to the scale of the refugee crisis). INGOs received 19 percent ( $\$ 25.8$ million) and $\mathrm{RCRC}$ received just 3 percent $(\$ 3.8$ million). ${ }^{27}$

Figure 9: First-level recipients of international humanitarian funding to Uganda by donor type, 2015

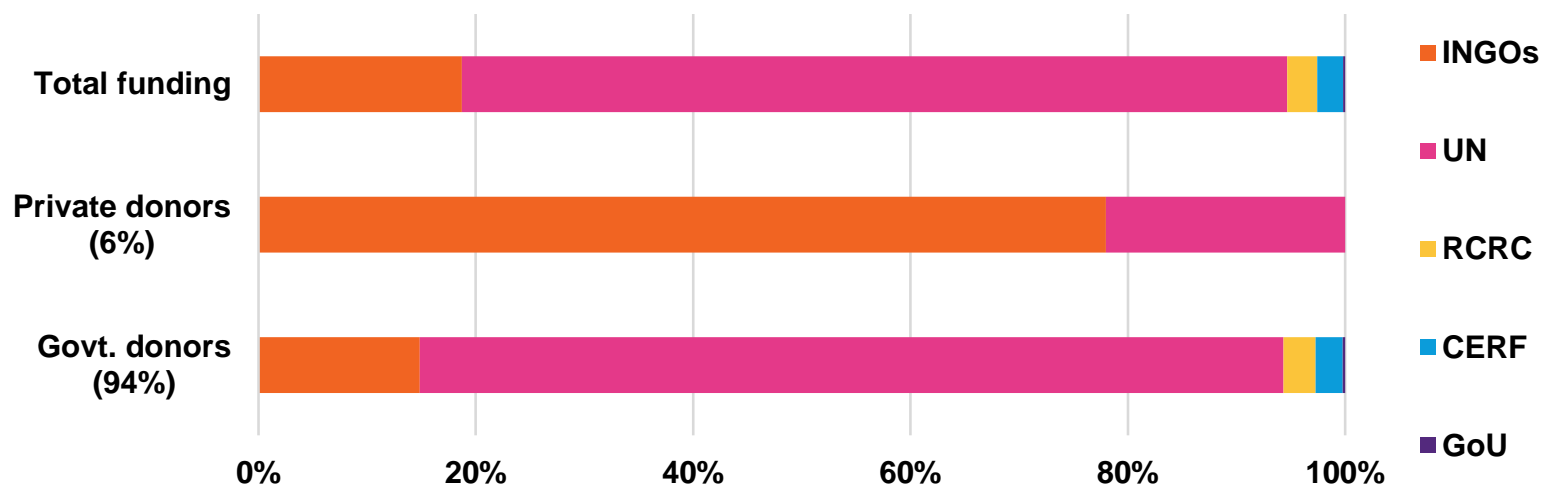

Sources: Development Initiatives based on UN OCHA FTS, OECD DAC CRS, CERF, and ICRC data, and primary data provided by study participants. 
UN agencies received the largest proportion of funding overall (76 percent), and funding from government donors, while INGOs received 78 percent of private funding investigated for this study. The remaining private funding was transferred to UN agencies.

Figure 10: International humanitarian funding to LNHAs in Uganda channeled through INGOs, UN agencies, and RCRC, 2015

INGOs UN agencies $\quad$ RCRC

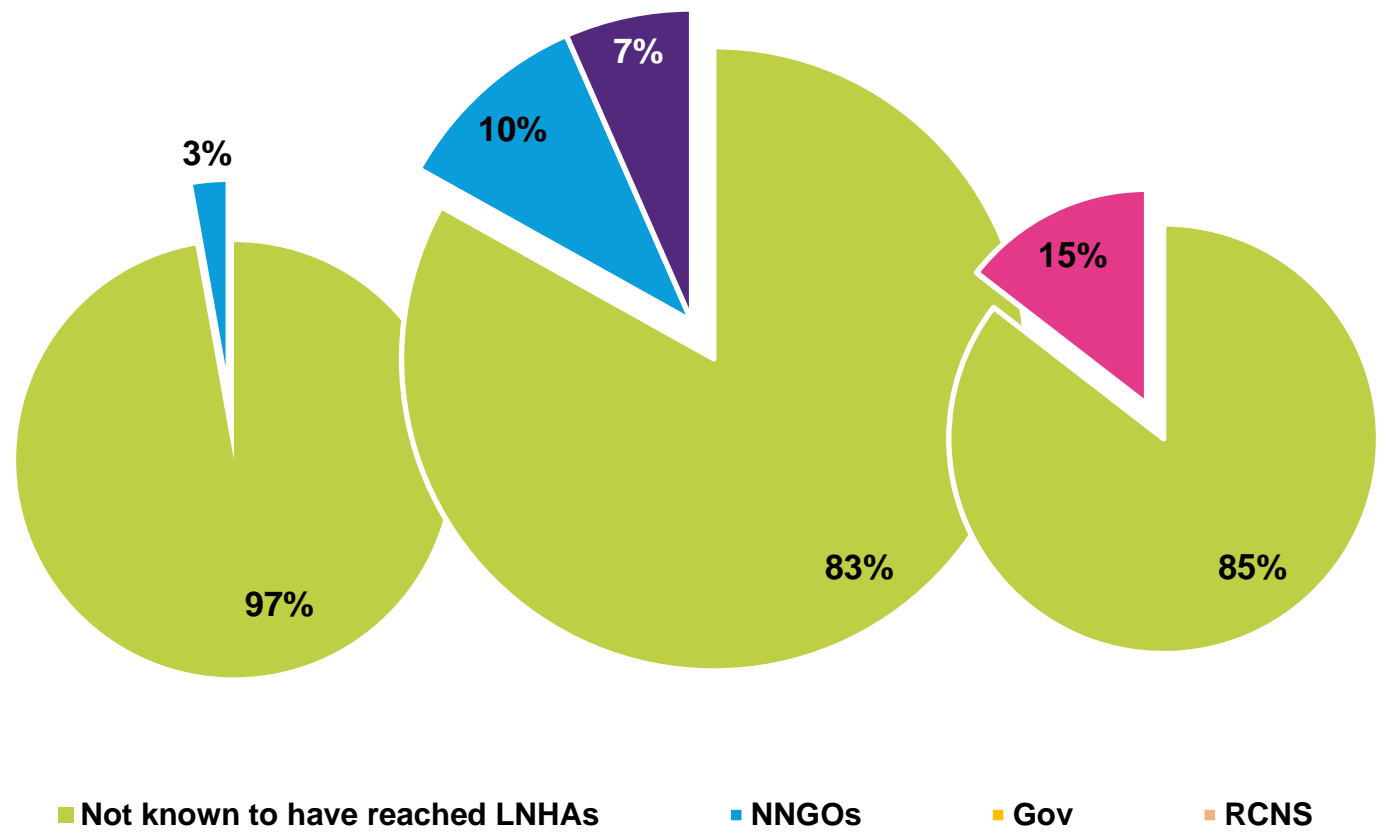

Sources: Development Initiatives based on UN OCHA FTS, OECD DAC CRS, CERF, and ICRC data, and primary data provided by study participants.

Data for Uganda aligns to findings from Bangladesh, which suggest that UN agencies transfer a greater share of the funding they receive to LNHAs than INGOs and RCRC. In Uganda, at least 17 percent of funding channeled through UN agencies was provided to LNHAs, while just 3 percent of funds channeled through INGOs, and 15 percent of funding channeled through RCRC, went to LNHAs. All funding channeled to LNHAs by RCRC went to the Uganda Red Cross Society, and all funding channeled to LNHAs by INGOs went to NNGOs.

61 percent of funds transferred to LNHAs by UN agencies went to NNGOs, with the remaining 39 percent provided to the GoU. However, all data on UN funding in Uganda for this study was shared by UNHCR, which appears to work more with LNHAs than other UN agencies. It was not clear, during the research process, why this appears to be the case, although it may be a result of UNHCR's leadership, but with more limited direct program implementation capacity, in the large-scale refugee response. 
Figure 11:International humanitarian funding received by LNHAs in Uganda by funding source, 2015

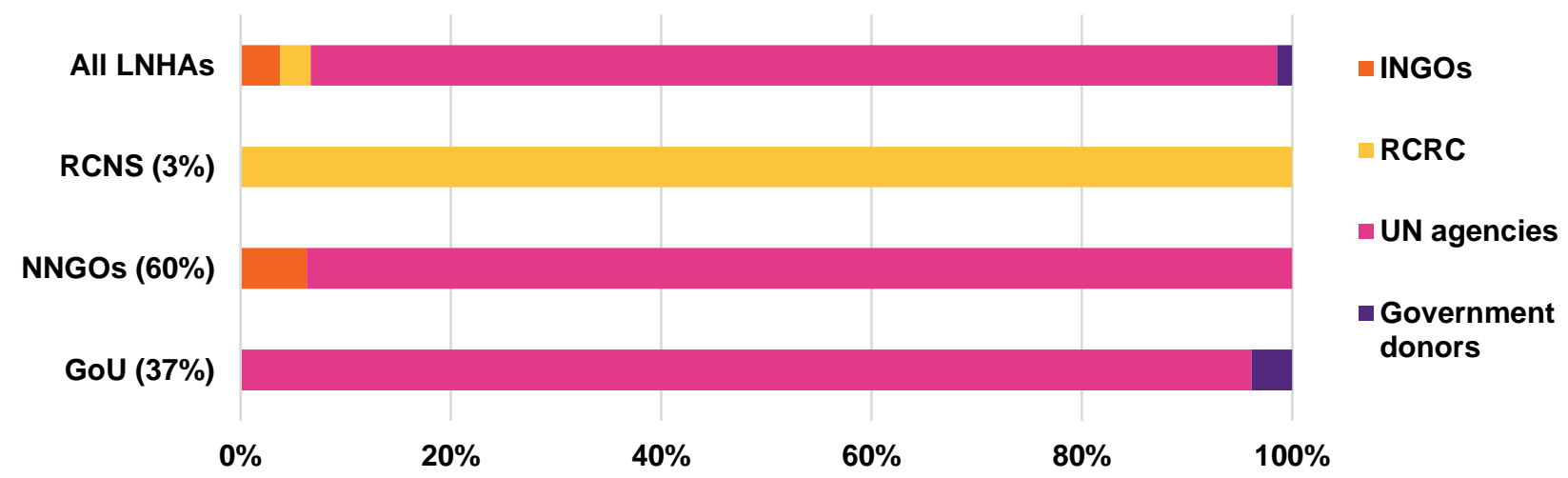

Sources: Development Initiatives based on UN OCHA FTS, OECD DAC CRS, CERF, and ICRC data, and primary data provided by study participants.

The UN was the main source of funding to the GoU and NNGOs, providing 96 percent and 94 percent, respectively, of all investigated funding they received. This reflects the fact that UN agencies received more international humanitarian funding than INGOs and RCRC and transferred a higher proportion to LNHAs than INGOs.

The extent to which the issues identified above, and others, may prohibit Uganda's domestic civil society from engaging in internationally-funded humanitarian response will need to be better understood before developing strategies to work towards building their role, as well as the volume of funding they access. Efforts may also be required to support the growth of domestic space for civil society implementing partners and further develop LNHAs' capacity to manage international government funding before or alongside any efforts to increase direct funding to and the role of LNHAs in Uganda. 


\section{FINDINGS THAT MATTER}

For over one year, since the signing of the Grand Bargain, debates around definitions of actors and funding systems have frustrated critics and proponents of the agenda alike-spurring questions on "how far progress can be made" or "what matters most." ${ }^{8}$ Moreover, recent reviews of global funding flows have provided important warning signs that those committed to localization have a long way to go to achieve the targets set by the Grand Bargain and other frameworks. ${ }^{29}$

This study helps highlight important dynamics that are vital for the way localization and humanitarian financing commitments move from discussion to delivery, based on learning from Bangladesh and Uganda.

\section{CONTEXT MATTERS}

LNHAs in Uganda appear to receive significantly less international humanitarian financing, both as a proportion of the total, and in terms of volume, than those operating in Bangladesh. $\$ 19.3$ million (12 percent) of a total $\$ 166$ million in Uganda is known to have been directly or indirectly transferred to LNHAs, compared to $\$ 24.6$ million (39 percent) of $\$ 62.5$ million in Bangladesh.

The reasons for this difference are not clear, but, as previously mentioned, the two countries represent very different contexts in terms of the types of crises typically affecting them and the capacity to manage these locally. Analysis in this report is based on those crises that were internationally funded in 2015: primarily, widespread flash floods in Bangladesh, and the South Sudan refugee crisis in Uganda, where both the scale of need and numbers of affected people varied. ${ }^{30}$

Relatedly, the differing systems and processes underpinning the delivery of humanitarian action in each country may also play a role, e.g., many of the remote communities affected by flooding in Bangladesh were primarily accessible to nearby LNHAs, whereas international actors had more limited access. In Uganda, international actors have long been present and established in the country's various refugee responses-where UNHCR plays a specific, focused leadership role. Other observed factors include the size, experience, and capacity of local actors, or legislation and regulations on civil society as a whole, as well as their involvement in decision-making spaces. The historical capacity strengthening investments in civil society may also play a role. Further research is required to uncover the most critical drivers of these differences, but even without it, the impact of these differences -in terms of the volume and proportion of international funding ultimately reaching domestic humanitarian actors-demonstrates why a national level, context-specific approach to implementing global-level commitments on the "localization" of humanitarian assistance is so important. 
Consider Bangladesh, where 20 percent of international humanitarian funding was provided directly to LNHAs-albeit to the GoB-with no instances of direct funding to NNGOs despite their well-recognized role in delivering assistance. Or consider Uganda, where almost no international funding was provided directly to LNHAs, and the number of operational LNHAs engaged in humanitarian responses remains small. In view of these differences, any processes or initiatives contributing to the Grand Bargain funding target will look decidedly different at the national level, and as such, should be defined in context.

Reflecting on the findings in this study, contextually-driven analysis will need to measure both volumes of funding flows to LNHAs at different levels (whether national or subnational), as well as tracking the type of actor, and how funding can be appropriately granted as directly as possible now and in the future. As domestic capacity to respond evolves, so should the investments. By tracking this contextual data, better decisions can be made about how to best support and invest in LNHAs. Moreover, it will also enable the setting of realistic targets to drive meaningful change in how the humanitarian financing system invests in capacity strengthening. Without it, global funding ambitions will likely remain far out of reach-glossing over the necessary-and, as a result, be quietly abandoned.

\section{"DIRECT" AND "INDIRECT" FUNDING MATTER, BUT NOT ONLY IN THE WAYS WE THOUGHT}

The perception of LNHAs interviewed for this study was that greater proximity to donors offers greater negotiating power and involvement in overall program management-most of the decisions regarding budget, design, and strategy of humanitarian responses have already been set by the donor and first-level recipient by the time funding reaches the local actor and implementing partner. At that stage, LNHAs reported, there is limited scope for strategy modifications or revisions to cover necessary organizational, core, or administrative costs. Furthermore, those interviewed suggest that a lack of information sharing, communication, and dialogue between actors sometimes resulted in project failure, delays in action, and contributed to relationship mistrust or other gaps.

As the overall pot of available humanitarian funding shrinks, LNHAs resort to partnering with a greater number of international actors to cover their costs, and the more complicated response delivery and reporting becomes: "Different monitoring staff come from different INGOs and instruct us to maintain stock registers in different ways. If one donor inserts a point, another donor deletes [it]. It makes our work complex," as one NNGO representative said. The call for greater direct funding to LNHAs should not be separated from calls to reduce duplication and management costs or increasing collaborative humanitarian multi-year planning and funding. ${ }^{31}$ Neither should they be separated from calls for equitable partnerships. ${ }^{32}$

Donors interviewed identify many reasons why indirect funding to LNHAs is more convenient, such as the relative lack of systems among domestic
The perception of LNHAs was that greater proximity to donors offers greater negotiating power and involvement in overall program management - most of the decisions have already been made between the donor and first-level recipient by the time funding reaches local actors. 
actors in meeting their reporting requirements and the impracticality of managing the number of grantees at country level that direct funding would necessitate. Indeed, examples were found where, despite operating lower down the financial chain, NNGOs felt valued and involved as partners, rather than merely subcontracted implementers. This demonstrates that quality of funding mechanisms and relationships are equally important to the volume of direct funding so long as the objective is to invest in LNHAs to achieve greater local ownership, engagement, and leadership.

The lack of access to significant direct funding may also be linked to a lack of access to, or limited participation in, high-level decision-making processes, which sit largely within other parts of the humanitarian architecture. While volume of funding received and directness of funding are important criteria, these metrics alone cannot serve as a proxy for making real shifts in how decisions are made within the humanitarian system at the country level. In fact, a few NNGOs reported that better direct communication and access to international donors and decision-making spaces (both national and international) were more important than increasing direct funding. Oxfam research in other countries has demonstrated that humanitarian assistance based on international actor priorities may ultimately be less effective when not driven by national strategies and decision-making. ${ }^{33}$ Further research is needed to understand the qualitative differences between direct and indirect funding and its implications on national strategies for humanitarian responses as well as the broader engagement of LNHAs in humanitarian coordination mechanisms. Regardless, pursuing direct funding routes to LNHAs alone is not enough-indeed, even as pathways to greater direct or indirect funding are explored, progress can be made to support LNHAs' meaningful engagement in humanitarian coordination and decision-making spaces.

At the global level, there is also an urgent need to understand how this qualitative difference between direct and indirect funding can be better reflected in the various commitments to local and national responders. Further analysis is needed to identify features of "quality" funding, which work for LNHAs (multi-year, unearmarked, sufficient overheads to support sustainable capacity, etc.) and how they can be measured and included within implementation of the Grand Bargain, as well as the Principles of Partnership signed in $2007^{34}$ —which were among the first global commitments to investing in better partnerships but have had limited follow-up.

\section{SUSTAINABILITY MATTERS}

The somewhat circular issue of financial sustainability also presents a problem for some LNHAs. Organizations often need to demonstrate sustainability to meet donor requirements but cannot be financially sustainable without access to the comparatively reliable, sustained international funding streams available to other implementing agencies and international actors. Moreover, some NNGOs reported being unable to pay adequate salaries to their staff when receiving indirect funding. One respondent in Bangladesh reported instances of INGOs and UN agencies retaining all administrative costs, in efforts to comply with donor requests to

\author{
Some NNGOs \\ reported that better \\ direct communication \\ and access to \\ international donors \\ and humanitarian \\ decision-making \\ spaces were more \\ important than \\ increasing direct \\ funding.
}


drive down "overheads," with no contribution to NNGO administration of the grant.

LNHAs may need to build their sustainability in other ways, such as through micro-finance and private partnerships. One NNGO interviewed in this study reported a funding model shift based on bank loans and micro-finance that has allowed the agency to no longer depend on international funding grants. Of course, shifts like these are not without their own challenges, as some NNGOs face difficulty in maintaining humanitarian competencies as they expand development work.

Therefore, international funding should include measures which strengthen an organization's overall capacity and sustainability, including funding administrative costs. ${ }^{35}$ This applies to the diverse range of funding tools currently available to LNHAs, whether targeted for capacity-strengthening like the European Union's Enhanced Response Capacity (ERC) and the UK's Disaster and Emergency Preparedness Programme (DEPP), or unearmarked pooled funds like UN-led Country Based Pooled Funds (CBPF). Practices that support LNHA financial sustainability should be encouraged by international actors-better still by LNHAs negotiating budgets with international agencies, when brought in early enough, to include program expenses and institutional overhead costs, as a requirement for partnership. ${ }^{36}$

\title{
THE GOVERNMENT MATTERS
}

Another more surprising finding identified through this research was a misconception among LNHAs in Bangladesh that international actors provide the largest amount of humanitarian funding, when in fact the GoB provided more-not just in 2015, but from 2012 through 2016. In addition, the only instances of direct funding in 2015 from international donors to LNHAs in Bangladesh and Uganda were to the governments.

The definition of local and national humanitarian actors includes government, based on recognition within international law of the primacy of the state in humanitarian responses, ${ }^{37}$ namely the central role government actors have in coordination and implementation of assistance. This inclusion has meant that new commitments for greater investments in LNHAs must extend also to governments.

In principle, including governments in the LNHA definition is logical and straightforward, yet this research identifies differences between government actors and other local and national actors, raising important questions.

First, considering the Grand Bargain and its next steps for donors, does it matter which local or national actor investments go to? Will improved humanitarian outcomes be met if greater direct humanitarian funding, primarily or even only, is given to governments (as was the case in 2015)?

\author{
"Government will be \\ the main actor of the \\ future and main \\ counterpart of any \\ NGO. As \\ Bangladesh heads \\ toward becoming a \\ middle-income \\ country, self- \\ reliance in terms of \\ funding and \\ implementation is \\ inevitable." \\ Christa Rader, WFP \\ Bangladesh
}

In the case of Bangladesh, government policy, legal frameworks, and investments over the past few decades in disaster risk reduction (DRR) have resulted in a significant decrease in the number of deaths caused by 
climate-related emergencies in the country. ${ }^{38}$ In Uganda, DRR policy was established more recently-in 2010 —and its corresponding legal framework is in development. ${ }^{39}$ Both countries' make explicit links between progressing DRR as part of national development processes, and that investments in DRR depend on-as a guiding principle - the participation of and collaboration with international, national, and local actors, as well as crisisaffected communities. ${ }^{40,41}$

Given this dependence, then, the more relevant question is, how do governments financially support local and national non-state responders' strengthened role in national responses systems, even as governments increase funding for humanitarian responses?

\section{DATA MATTERS}

In most countries, domestic spending on humanitarian crises is not reported publicly, making it difficult to study it at country level or globally. Although out of the scope of this research, there is a clear need to assess the funding flows from governments to civil society and NGOs in country, to improve targeting of new investments following the Grand Bargain.

But that is not all: the push around localization has come from a diverse range of actors including national actors and INGOs, like Oxfam and others in the Charter4Change network. In Bangladesh and Uganda, international humanitarian actors have invested in a wide range of important initiatives to strengthen the role of LNHAs in emergency responses-many of which have been driven by long-standing relationships between INGOs and their local and national partners.

However, this has led to an assumption within the sector that many INGOs are already there -already sharing the largest amounts of funding and resources with LNHAs. In the humanitarian context of 2015 in Bangladesh and Uganda, however, this seems not to be the case. In fact, the financial data identified in Oxfam research tells a different story: UN agencies appeared to transfer a greater proportion of their funding to LNHAs than INGOs. Certainly, in Bangladesh and Uganda, UN agencies' investment in partnership was important, as without it many LNHAs would not have had enough resources to deliver vital assistance. ${ }^{42}$

More detailed, standardized, timely, and accurate publicly available information on a broader range of resources contributing to crisis response at country (or crisis) level and where they come from, including national budgets, would help address the significant gaps in knowledge - and lead to better targeting of humanitarian funding. 


\section{CONCLUSIONS AND RECOMMENDATIONS}

This report shows that the Grand Bargain's global aggregated target for financially investing in LNHAs is important to build coherence and momentum around the localization debate. Yet it risks losing meaning at the national level, in light of the significant differences in contexts and funding dynamics. Greater and better contextual and financial analysis is necessary to understand where specific investments should be made.

While funding data is an essential part of the conversation, it cannot end there. ${ }^{43,44}$ The over-simplification of localization to a discussion of "more money" masks a central ask of those interviewed in this study for serious commitment and accountability to changing the terms of funding relationships within the financial chain-and LNHA engagement in budget allocations, program design, broader coordination, and involvement in strategic decision-making and priority setting.

Change will not be quick-and the sector must see its localization commitments as a long-term, strategic process to realize a better-designed humanitarian system.

Oxfam makes the following recommendations as necessary next steps to drive change where it is most needed-the local level:

\section{Local and national NGOs and CBOs, Red Cross or Red Crescent National Societies should:}

- Prepare for change: Reflect on the changing role of LNHAs in internationally-funded humanitarian responses and develop strategic organizational plans for greater engagement in national decision-making, stronger funding management to support funding "as directly as possible," quality of programs and partnerships, and accountability to humanitarian standards.

- Think differently about humanitarian funding sources: Work towards diversifying both income streams-including through domestic resource mobilization, where possible-as well as government and international partners, to support growth and sustainability. Relatedly, pursue alternative budgeting strategies in existing or new partnerships to include overhead or core administrative costs.

\section{- Drive accountability to change:}

- Push national governments, donors, and other funding partners for greater access to funding "as directly as possible," and for inclusion of overhead/core administrative costs, particularly from signatories to the Grand Bargain and Charter4Change. This could be pursued by advocating for common cost classification in the Grand Bargain Workstream on Reducing Duplication and Management Costs (4). 
- Insist, where possible, on being included in the process of developing humanitarian response budgets, programs, and strategies with all international partners, as a condition of partnership.

- Participate in and promote wider engagement of LNHAs in humanitarian coordination mechanisms.

\section{The Governments of Bangladesh and Uganda should:}

\section{- Allocate humanitarian funding:}

- Ensure that national budgets allocate funding for disaster management at the federal and subnational level, and explore avenues to fund responders, both state and non-state, with overhead/core administrative costs, for relief services in districts cyclically or regularly affected by humanitarian crises.

- Make available specific funding for NGO and CBO capacity strengthening in humanitarian responses.

- Publish national funding to emergencies: Improve the transparency of humanitarian assistance by publishing data on aid flows in a standardized, open source format. Data should integrate commitments and disbursements by donor, sector, and public funding recipient, as well as enable tracing of funds from donor source to ultimate recipient/provider of assistance, in order to accurately assess the overall volume of funding reaching LNHAs. Ensure this information includes national funding, is publicly available, and is regularly updated.

- Encourage diverse and quality partnerships: Promote a greater number of, and more equitable humanitarian partnerships between, humanitarian actors operating in-country.

- Support community and NNGO humanitarian leadership: Facilitate and strengthen mechanisms for the participation of affected populations and civil society in defining local and national humanitarian priorities, and in humanitarian coordination mechanisms at the governmental level and within international clusters.

\section{The Grand Bargain signatories should:}

- Meet the commitment: Open more avenues for, and provide greater volume of, direct and indirect humanitarian funding to LNHAs.

- Prioritize context-specific analysis and approaches to deliver on Grand Bargain commitments, including but not limited to the "Localization" commitment: "more support and funding tools for local and national responders." At a minimum, measure national funding flows in "demonstrator" or prioritized countries, to establish a baseline and set realistic targets for progress at the national level.

\section{- Link workstreams within the Grand Bargain:}

- Publish transparent, timely, high-quality funding data to the IATI Standard, connecting Grand Bargain Workstreams on Greater Transparency (1) and Localization (2) to accelerate progress, recognizing localization funding outcomes must be driven by nationallevel change based on greater information. 
- Connect Grand Bargain Workstreams on Localization (2), Reducing Duplication and Management Costs (4), and Multi-Year Planning and Funding (7) through guidelines that insist on sufficient planning timelines for proposal development, which includes the engagement of local and national partners during the response design and budgeting processes, and in sharing of adequate administrative support as part of partnership harmonization.

This research also highlighted other important gaps in knowledge which will influence the ways in which global commitments to local actors are realized. Oxfam recommends the following additional reviews:

- Qualitative accountability tools: Review the qualitative differences in direct and indirect funding partnerships with LNHAs and develop accountability tools ${ }^{45}$ to support equitable partnerships for greater quality funding.

- The effect of funding on humanitarian leadership: Further review how the differences in direct and indirect funding affect access to decisionmaking and the implications of this difference on national strategies for humanitarian responses and LNHA participation in humanitarian coordination mechanisms.

- Comparative analysis on drivers of funding difference to local actors between different countries: Given the variations in funding flows to local actors in Bangladesh and Uganda, more analysis is needed between a greater number of countries to understand the drivers of difference in existing funding relationships at the country level.

- Crisis-affected government funding to local and national actors: Recognizing the growing significance and contributions of government leadership in humanitarian responses, further review of national funding flows can support improved targeting of investments-both by government and international actors. 
1 This document was part of ongoing discussions within the IASC Humanitarian Financing Task Team (HFTT), Localisation Marker Working Group. The final document, Definition Paper, was published in January 2018 and retains the definitions used in this paper. Available at:

https://interagencystandingcommittee.org/system/files/hftt localisation marker definitions paper 24 january 2018.pdf

2 Development Initiatives, 2017. Global Humanitarian Assistance Report 2017. Available at http://devinit.org/wp-content/uploads/2017/06/GHA-Report-2017-Full-report.pdf

3 High Level Panel on Humanitarian Financing, Report to the UN Secretary General January 2016. Too important to fail: addressing the humanitarian financing gap. Available at https://reliefweb.int/sites/reliefweb.int/files/resources/\%5BHLP\%20Report\%5D\%20To0\%20i mportant\%20to\%20fail\%E2\%80\%94addressing\%20the\%20humanitarian\%20financing \%20 gap.pdf, pg. 20.

4 The definition of "as directly as possible" includes pooled funding and funding channelled through one intermediary (in this report called "indirect"). The definition is currently being tested because of debate. See for example: Devex (2017). Dispute over 'Grand Bargain' localization commitment boils over. Available at https://www.devex.com/news/dispute-overgrand-bargain-localization-commitments-boils-over-90603

5 For example, the Principles of Partnership established in 2017, but also other commitments in the Grand Bargain or the Charter4Change. See

https://www.icvanetwork.org/system/files/versions/Principles\%20of\%20Parnership\%20Engli sh.pdf and https://charter4change.org/

6 Grand Bargain, May 2016. Available at: https://reliefweb.int/sites/reliefweb.int/files/resources/Grand Bargain final 22 May FINAL2.pdf

7 For the full methodology, see: Els, C. (2017). Methodology for Assessing Humanitarian Funding Flows to Local and National Actors. Oxfam. https://policypractice.oxfam.org.uk/publications/methodology-for-assessing-humanitarian-funding-flowsto-local-and-national-acto-620323

8 The interruptions were due largely to unpredictable personal circumstances faced by the researcher, causing a shift in the timeline and approach to data collection. Adaptation of the data collection was led by the methodology designer to ensure that data collection was sufficient to provide useful comparisons.

9 A more detailed Bangladesh report will be published in 2018. The data collected for this study in Uganda will be part of further research and advocacy at the national level.

10 Indeed, current humanitarian reporting practices are fairly limited to recording and reporting only to the level of detail required by donors and the country an organization works in. More disaggregated data is difficult to come by and where organizations do collect it internally, it is often not done so systematically and in a way that is comparable with data from other organizations.

11 This study predates the recent influx of Rohingya refugees into Bangladesh.

12 LNHAs reported a further $\$ 42,600$ of direct funding from international actors for this study, but due to limitations in the comparability of data provided it could not be included in the analysis as it was not possible to confirm the source of funds.

13 Global Facility for Disaster Reduction and Recovery (GFDRR). See: https://www.gfdrr.org/bangladesh

14 Development Initiatives, 2016. Global Humanitarian Assistance Report 2016. Available at http://devinit.org/wp-content/uploads/2016/06/Global-Humanitarian-Assistance-Report2016.pdf. For recent refugee figures, see also UNHCR. (2017). Bangladesh: 24 November 2017. Operational Update.

http://reporting.unhcr.org/sites/default/files/UNHCR\%20Bangladesh\%20Weekly\%200perati onal\%20Update\%20-\%2024NOV17.pdf

15 Note that the data used for this study spans the calendar year of 2015 . The humanitarian picture in Bangladesh will likely now have changed significantly given the scale of needs, new appeal, and global focus on the Rohingya crisis.

16 National Budget MODM and MOF, GoB. The budgeted figures for GoB-DDM were given in BDT crore, which were converted into \$m using yearly average exchange rates (OANDA, Average Exchange Rates). Annual figures for GoB expenditure relate to the government's fiscal year, which runs from July to June.

17 Figures for international humanitarian funding over the five-year period between 2012 and 
2016 are taken from the UN OCHA FTS. International humanitarian funding identified in and analyzed for this study includes primary data on funding reported by a number of contributors, combined with publicly available data from the CRS and FTS, and only covers 2015 . The two are therefore not directly comparable, and a higher figure was identified for this study. It should be noted that not all international funding is reported to FTS, including some members of the RCRC movement and a number of "non-traditional" donors.

18 The Government of Japan provided over $\$ 26 \mathrm{~m}$ to the GoB, of which $\$ 23 \mathrm{~m}$ was used for one single project in disaster prevention and preparedness (improvement of meteorological radar systems in Dhaka and Rangpur). Source: OECD, OECD-CRS, Microdata for Creditor Reporting System (CRS).

19 Japan International Cooperation Agency. Details of activities for the Project for Improvement of Meteorological Radar System in Dhaka and Rangpur. Available at:

https://www.jica.go.jp/bangladesh/english/activities/activity14 $01 \quad 08 . h t m l$

$20 \mathrm{LNHAs}$ reported a further $\$ 42,600$ of direct funding from international actors for this study, but due to limitations in the comparability of data provided it could not be included in the analysis as it was not possible to confirm the source of the funds.

21 As previously noted, the GoB funds the majority of humanitarian activities in Bangladesh. Further research is recommended to identify the scope of the government's role in equivalent domestic processes, and therefore its role in setting the overall national agenda.

22 Some LNHAs view this mistrust as a kind of bias towards "brand names": as INGOs represent an "international brand" that is trusted or known, they are preferred by international donors.

23 United Nations Uganda and the World Bank, February 2017. Refugee and Host Population Empowerment (ReHOPE) Strategic Framework. Available at: https://ugandarefugees.org/files/documents/rehope/FINAL\%2008.03.17\%20ReHoPE\%20Strategy \%20-\%20clean\%20version.docx

24 According to the Uganda National Food Security Assessment Report, January 2017. Available at: http://www.necocopm.go.ug/assessments/1.\%20National\%20Food\%20Security\%20Assessement\%20Report\%20Ja nauary\%202017.pdf

25 UN Uganda and World Bank, February 2017. ReHOPE Strategic Framework. Annex A Strategic Context and Rationale, pg. 27.

26 World Bank Databank. See http://databank.worldbank.org/data/download/GNIPC.pdf

27 This excludes carry-over and transfers from within and across UN agency budgets allocated for that year, totalling $\$ 28.1$ million.

28 See for example, Marc DuBois. July 2017. The Good, the Bad, and the Ugly of Localization. Available at; http://www.humanicontrarian.com/2017/07/06/the-good-the-bad-and-the-ugly-oflocalization/

29 See for example, Development Initiatives, 2016. Global Humanitarian Assistance Report 2016, pg. 70. Available at http://devinit.org/wp-content/uploads/2016/06/Global-Humanitarian-AssistanceReport-2016.pdf, and in Local2Global Protection October 2017. Available at: https://www.local2global.info/research/grand-bargain-signatories-funding-to-local-responders

30 The more recent influx of Rohingya refugees, and an increasing number of international actors, changes the humanitarian context in Bangladesh significantly.

31 Grand Bargain Commitments 4 and 7.

32 Global Humanitarian Platform, July 2007. Principles of Partnership: A Statement of Commitment. Available at: https://icvanetwork.org/system/files/versions/Principles\%20of\%20Parnership\%20English.pdf

33 Saieh, A. Abi Khalil, A. and Gorevan, D. (2017). Making Aid to Jordan and Lebanon Work. Oxfam. Available at: https://www.oxfam.org/sites/www.oxfam.org/files/bn-making-aid-jordan-lebanon-work200417-en.pdf

34 Global Humanitarian Platform, July 2007. Principles of Partnership: A Statement of Commitment. Available at: https://icvanetwork.org/system/files/versions/Principles\%20of\%20Parnership\%20English.pdf

35 Delaney, M. Lydia Poole, L. and Kumara, S. (2016). Let Your Voice Be Heard: Improving Humanitarian Response, 2, 10-12 (December 2015). Available at: http://static1.squarespace.com/static/5625034fe4b092a567cf8a26/t/5707290fd210b84ce6bcc8cf/1 460087058841/Let+Your+Voice+be+Heard.pdf

36 See for example, A Single Drop for Safe Water (NNGO in the Philippines). 2016 Project Designing and Planning Guidance. Available at: http://www.singledrop.org/wp-content/uploads/2016/07/4.Project-Designing-Planning-2016.pptx

37 UN General Assembly. Strengthening of the Coordination of Humanitarian Emergency Assistance 
of the United Nations, GA Resolution 46/182, UN GAOR, 46th Sess., 78th plenary meeting, Annex, I.4, UN Doc A/RES/46/182 (1991); the UN International Law Commission's Draft Articles on the Protection of Persons in the Event of Disasters (Reports of the Special Rapporteur).

38 Centre for Research on the Epidemiology of Disasters. (2015). The Human Cost of Natural Disasters: A global perspective. Available at: https://reliefweb.int/sites/reliefweb.int/files/resources/PAND report.pdf

39 Government of Uganda, September 2010. The National Policy for Disaster Preparedness and Management. Available at: https://www.preventionweb.net/files/21032 ugandanationalpolicyfordisasterprep.pdf

40 lbid.

41 Government of Bangladesh. 2010 and 2016. National plans for disaster management 2010-2015, and 20162020. Available at:

http://modmr.portal.gov.bd/sites/default/files/files/modmr.portal.gov.bd/page/d29d2089 63434641 9b52 38e0c134a1f4/20-12-2015\%20\%281\%29.docx and http://modmr.portal.gov.bd/sites/default/files/files/modmr.portal.gov.bd/page/a7c2b9e1 6c9d 4ecf bb53 ec74653e6d05/NPDM\%2820162020\%29 Draft\%2003\%20April\%20\%202017\%20\%281\%29.docx

42 In Uganda, Oxfam's research did not receive direct input from all UN agencies, nor did it conduct a comparative study of partnership models with UN agencies, and their capacity for direct implementation. These are factors that needs to be taken into consideration for future analysis.

43 Trocaire and Group URD. (2017). More than the Money: Localization in Practice. Available at: https://www.trocaire.org/resources/policyandadvocacy/more-than-the-money-localization-practice

44 Australian Red Cross. (2017). Going Local: Achieving a more appropriate and fit-for-purpose humanitarian ecosystem in the Pacific. Available at:

https://www.redcross.org.au/getmedia/fa37f8eb-51e7-4ecd-ba2f-d1587574d6d5/ARC-Localizationreport-Electronic-301017.pdf.aspx

45 For example, an accountability tool may be developed to assess international partners' ability to support better quality direct and indirect funding, including number of years of funding, whether earmarked, if there exist sufficient overheads or capacity strengthening, etc. 
This paper was written by Chloe Parrish, Development Initiatives, and Anita Kattakuzhy, Oxfam. Oxfam expresses its sincerest thanks to the local, national, and international humanitarian actors in Bangladesh and Uganda who provided financial data and gave time to this report. Oxfam acknowledges the research design and data collection support of Christian Els and Farzana Khan, as well as the assistance of Sophia Swithern, Kirsten Hagon, Petra Righetti, Suying Lai, Valerie Bey, Mariana Merelo Lobo, Lily Gardner, Tara Gingerich, and Maya Kapsokavadis in its production. It is part of a series of papers written to inform public debate on development and humanitarian policy issues.

For further information on the issues raised in this paper please email advocacy@oxfaminternational.org

This publication is copyright but the text may be used free of charge for the purposes of advocacy, campaigning, education, and research, provided that the source is acknowledged in full. The copyright holder requests that all such use be registered with them for impact assessment purposes. For copying in any other circumstances, or for reuse in other publications, or for translation or adaptation, permission must be secured and a fee may be charged. Email policyandpractice@oxfam.org.uk

The information in this publication is correct at the time of going to press.

Published by Oxfam GB for Oxfam International under ISBN 978-1-78748-213-5 in March 2018. DOI: $10.21201 / 2017.2135$

Oxfam GB, Oxfam House, John Smith Drive, Cowley, Oxford, OX4 2JY, UK.

\section{OXFAM}

Oxfam is an international confederation of 20 organizations networked together in more than 90 countries, as part of a global movement for change, to build a future free from the injustice of poverty. Please write to any of the agencies for further information, or visit www.oxfam.org

Oxfam America (www.oxfamamerica.org)

Oxfam Australia (www.oxfam.org.au)

Oxfam-in-Belgium (www.oxfamsol.be)

Oxfam Brasil (www.oxfam.org.br)

Oxfam Canada (www.oxfam.ca)

Oxfam France (www.oxfamfrance.org)

Oxfam Germany (www.oxfam.de)

Oxfam GB (www.oxfam.org.uk)

Oxfam Hong Kong (www.oxfam.org.hk)

Oxfam IBIS (Denmark) (http://oxfamibis.dk/)
Oxfam India (www.oxfamindia.org)

Oxfam Intermón (Spain) (www.oxfamintermon.org)

Oxfam Ireland (www.oxfamireland.org)

Oxfam Italy (www.oxfamitalia.org)

Oxfam Japan (www.oxfam.jp)

Oxfam Mexico (www.oxfammexico.org)

Oxfam New Zealand (www.oxfam.org.nz)

Oxfam Novib (Netherlands) (www.oxfamnovib.nl)

Oxfam Québec (www.oxfam.qc.ca)

Oxfam South Africa (www.oxfam.org.za)

\section{development initiatives}

